\title{
Systematic and Functional Aspects of the Locomotor System of the Scrub-birds, Atrichornis, and Lyrebirds, Menura (Passeriformes: Atrichornithidae and Menuridae)
}

\author{
ROBERT J. RAIKOW \\ Department of Biological Sciences, University of Pittsburgh, \\ Pittsburgh, Pennsylvania 15260, U.S.A. \\ and \\ Section of Birds, Carnegie Museum of Natural History, \\ Pittsburgh, Pennsylvania 15213, U.S.A.
}

\begin{abstract}
The forelimb and hindlimb musculature was dissected in the Noisy Scrub-bird, Atrichornis clamosus (Atrichornithidae), and the Superb Lyrebird, Menura novaehollandiae (Menuridae). The purposes of the study were to test certain phylogenetic hypotheses and to examine the locomotor specializations of the Menurae. The two families share derived myological traits and are sister groups. The structure of M. flexor perforatus digiti IV confirms that their affinities are with the oscines and not with the suboscines. The scrub-birds have the more highly derived limb morphology. The Menurae exhibit several myological conditions not shared with the Ptilonorhynchidae, other members of the 'corvid assemblage' or other passerines. They are, therefore, not similar to the bowerbirds in their limb musculature. A sister-group relationship with bowerbirds is not ruled out, however, because the peculiarities of the Menurae could have evolved after separation from a common ancestor with the bowerbirds, but the same is true for any suggested sister group.

Both scrub-birds and lyrebirds are nearly flightless. Atrichornis has reduced clavicles and greater forelimb reduction than does Menura. In contrast, Menura shows greater specialization in the hindlimb, which is elongated and has enlarged claws specialized for digging and grasping.
\end{abstract}

RAIKOW, RoBert J., 1985. Systematic and functional aspects of the locomotor system of the scrub-birds, Atrichornis, and lyrebirds, Menura (Passeriformes: Atrichornithidae and Menuridae). Records of the Australian Museum 37(4): 211-228.

KEYWORDS: Atrichornithidae, forelimb, hindlimb, Menuridae, Menurae, morphology, myology.

Two families of Australian passerines, the Menuridae (lyrebirds) and Atrichornithidae (scrub-birds), have puzzled systematists for over a century. While generally considered closely related to each other, their affinities to other birds have remained unclear. Although they bear little resemblance to suboscines, they have been classified as a suborder Menurae within the order Passeriformes (Wetmore, 1960). The question of their relationships was reopened by Sibley (1974) who studied the electrophoretic patterns of the egg-white proteins of Menura and reviewed other data, especially relating to anatomy and behaviour. He concluded that the Menuridae are oscine and are most closely related to the bowerbirds (Ptilonorhynchidae) and birds-ofparadise (Paradisaeidae) within a radiation of Australasian 'corvine' families. Because of the presumed relationship of the Atrichornithidae to the Menuridae, Sibley also suggested that the former family be placed next to the Menuridae in the suborder Passeres (oscines), although he did not study the proteins of the scrubbirds. Sibley $(1974,1976)$ reviewed the history of the problem.

More recently, Sibley \& Ahlquist (ms.) reinvestigated this problem using the technique of DNA-DNA hybridization. Their study supported the sister-group relationship of the Atrichornithidae and Menuridae, and also indicated that these families are in turn most closely related to the Ptilonorhynchidae. Surprisingly, however, the Ptilinorhynchidae and Paradisaeidae were found to be widely separated on the basis of the DNA analysis, so Sibley no longer hypothesizes a close relationship of the birds-of-paradise with the lyrebirds and scrub-birds. 